\title{
Effect of aqueous extract of Mikania micrantha Kunth on seed germination and seedling growth of Cassia tora $\mathrm{L}$.
}

\author{
Kishor Kumar Mishra \\ Department of Botany, M.M.A.M. Campus, T.U., Biratnagar, Nepal \\ *E-mail: kishorkumarmishra@gmail.com
}

\begin{abstract}
The order of inhibitory effectiveness of various parts of Mikania micrantha on seed germination and seedling growth of Cassia tora was leaf >stem> inflorescence. The dry weight of C. tora seedlings was lowest under $25 \%$ concentration of leaf extract, and highest under treatment with 5\% concentration of inflorescence extract of M. micrantha.
\end{abstract}

Key words: Invasive alien species (IAS), allelopathy, seed germination

\section{Introduction}

Mikania micrantha Kunth (Asteraceae) is an Invasive alien weed that has become a menace in the tropical and subtropical regions of Nepal. It has become aggressive due to its high seed output,wind-dispersed seeds, fast growth, perennation by rootstock, vegetative propagation combined with adaptations to thrive well in adverse climatic conditions (Sasikumar, 1999). It inhibits growth of many plants by its smothering effect and some compounds leaching out from withered parts. The allelopathic potential of this aggressive weed was assessed in the present study on Cassia tora L. (Leguminosae, subfamily Caesalpinioideae ) which grows in open areas along with M. micrantha .

\section{Materials and Methods}

The stem, leaf and inflorescensce of M. micrantha were collected on $23^{\text {rd }}$ December 2015 from the premises of MMAM campus, and dried in an oven at $60^{\circ} \mathrm{C}$ for $24 \mathrm{hr}$. The dried materials were then powdered and stored in polythene pouches until the commencement of the experiment. In the first week of May 2016, $10 \mathrm{~g}$ each of the powders was put in $100 \mathrm{ml}$ distilled water separately and kept for $72 \mathrm{~h}$. The extracts were then filtered with Whatman N0 1 filter paper. The filtrates were made up to $100 \mathrm{ml}$ in a conical flask. From these stock solutions different dilutions like 5,10,15,20 and $25 \%$ were made.

Five month old air-dried seed of $C$. tora were scarified using concentrated sulphuric acid for 15 minutes. The solutions of different concentration were given to those seeds as medium for germination and growth. Three replicates, with 20 seeds in each treatment at room temperature were employed. A control was also kept with 3 replicates, with water as a medium. Germination and growth were noted after five days.

\section{Results and Discussion}

Among the different extracts of $M$. micrantha, leaf extract had the highest inhibitory effect on seed germination, and length and weight of radicle and plumule of $C$. tora (Table 1). It indicated the presence of allelochemicals in sufficient quality in the leaf extract to reduce the rate of cell division (Avers \& Goodwin, 1956), activate the growth retarding hormones 
(Gleissman \& Phinny, 1972), and interference with oxidative phosphorlylation (Demos et al., 1975) of the test species.

The 5\% concentration of leaf extract and some higher concentrations of stem and inflorescence extract of M. micrantha promoted germination and seedling growth of the test species. These observations get support from the conclusion of Rice (1984) that most compounds that are inhibitory at some concentrations are stimulatory to the same processes in minute concentrations. It may be concluded from the present study that leaf is the major site for synthesis of allelochemicals in M. micrantha.

Table 1. Effect of aqueous extract from different parts of M. micrantha on seed germination, linear growth and dry weight of radicles and plumules of $C$. tora after 5 days (meant $\pm \mathrm{SE}$ ).

\begin{tabular}{|c|c|c|c|c|c|c|}
\hline \multirow{2}{*}{ Parts } & \multirow{2}{*}{$\begin{array}{c}\text { Concen- } \\
\text { tration }(\%)\end{array}$} & \multirow{2}{*}{$\begin{array}{l}\text { Germina- } \\
\text { tion }(\%)\end{array}$} & \multicolumn{2}{|c|}{ Length $(\mathrm{cm})$} & \multicolumn{2}{|c|}{ Dry weight (mg) } \\
\hline & & & Radicle & Plumule & Radicle & Plumule \\
\hline Control & 0 & $64 \pm 3$ & $2.5 \pm 0.5$ & $3.3 \pm 0.6$ & $1.4 \pm 0.4$ & $2.5 \pm 0.5$ \\
\hline \multirow[t]{5}{*}{ Leaf } & 5 & $67 \pm 4$ & $2.4 \pm 0.5$ & $2.9 \pm 0.5$ & $1.2 \pm 03$ & $22 \pm 0.5$ \\
\hline & 10 & $58 \pm 3$ & $1.9 \pm 0.4$ & $2.1 \pm 0.4$ & $1.1 \pm 0.3$ & $2.2 \pm 0.5$ \\
\hline & 15 & $55 \pm 3$ & $1.8 \pm 0.4$ & $1.8 \pm 0.4$ & $1.1 \pm 0.3$ & $2.0 \pm 0.4$ \\
\hline & 20 & $51 \pm 3^{*}$ & $1.6 \pm 0.4^{*}$ & $1.7 \pm 0.4 *$ & $1.0 \pm 0.3$ & $1.7 \pm 0.4$ \\
\hline & 25 & $48 \pm 3 *$ & $1.5 \pm 0.4^{*}$ & $1.5 \pm 0.4 *$ & $0.9 \pm 0.3$ & $1.2 \pm 0.3$ \\
\hline \multirow[t]{5}{*}{ Stem } & 5 & $63 \pm 3$ & $2.3 \pm 0.5$ & $3.5 \pm 0.6$ & $0.9 \pm 0.3$ & $2.5 \pm 0.5$ \\
\hline & 10 & $65 \pm 3$ & $2.2 \pm 05$ & $3.0 \pm 0.5$ & $1.0 \pm 0.3$ & $2.4 \pm 0.5$ \\
\hline & 15 & $70 \pm 4$ & $2.2 \pm 0.5$ & $2.6 \pm 0.5$ & $1.0 \pm 0.3$ & $2.3 \pm 0.5$ \\
\hline & 20 & $68 \pm 4$ & $1.9 \pm 0.4$ & $2.3 \pm 0.5$ & $1.0 \pm 0.3$ & $2.3 \pm 0.5$ \\
\hline & 25 & $67 \pm 4$ & $1.7 \pm 0.4$ & $1.8 \pm 0.4 *$ & $0.9 \pm 0.3$ & $2.0 \pm 4$ \\
\hline \multirow[t]{5}{*}{ Inflorescence } & 5 & $65 \pm 4$ & $2.7 \pm 0.5$ & $2.8 \pm 5$ & $1.7 \pm 0.4$ & $2.7 \pm 0.5$ \\
\hline & 10 & $58 \pm 3$ & $2.6 \pm 0.5$ & $2.7 \pm 0.5$ & $1.6 \pm 0.4$ & $2.6 \pm 0.5$ \\
\hline & 15 & $67 \pm 4$ & $2.4 \pm 0.5$ & $2.3 \pm 0.5$ & $1.8 \pm 0.4$ & $2.4 \pm 0.5$ \\
\hline & 20 & $62 \pm 3$ & $2.3 \pm 0.5$ & $2.0 \pm 0.4$ & $1.5 \pm 0.4$ & $2.3 \pm 0.5$ \\
\hline & 25 & $75 \pm 4$ & $2.2 \pm 0.5$ & $1.6 \pm 0.4 *$ & $1.4 \pm 0.4$ & $2.3 \pm 0.5$ \\
\hline
\end{tabular}

* Means differ significantly at $1 \%$ level

\section{Acknowledgements}

Author is thanful to Prof. Dr. Sasinath Jha, P.G. Campus, Biratnagr, for suggestions and to Prof. Mahendra Narayan Yadav, Campus chief, MMAM Campus, Biratnagar, for facilities.

\section{Reference}

Avers, C.J. \& R.H Goodwin 1956. Studies on roots .IV. Effects of coumarin and scopoletion on the standard root growth pattern of Phleum pratense. American Journal of Botany 43:612-620.

Demos, E.K., M. Woolwine, R.H. Wilson \& C. McMillan 1975. The effects of 10 phenolic compounds on hypocotyle growth and mitochondrial metabolism in mungbean. American Journal of Botany 62: 97-102.

Gleissman, T.A. \& B.O. Phinny 1972.Tannins as gibberellin antagonist. Plant Physiology 49: 323-330.

Rice, E.L. 1984. Allelopathy, $2^{\text {nd }}$ edn. Academic Press, Orlando, Florida

Sasikumar 1999. Allelopathic potential of Mikania cordata (Burm f ) Robins on Cassia occidentalis L.GEOBIOS 26: 72-74. 